\title{
AESTHETICS OF THE ARAB EMIRATES ENVIRONMENT AND ITS REFLECTION IN THE STYLECONTEMPORARY ARTIST ABDUL QADER MOHAMMED AL RAIS
}

\author{
Mahmmoud Husein Abdul Rahman Hussein \\ Iraqi Natural History Museum and Research Center
}

DOI: $10.37648 /$ ijrssh.v10i01.027

Received:06 ${ }^{\text {th }}$ October 2019; Accepted:25th November, 2019; Published: $04^{\text {th }}$ December, 2019

\begin{abstract}
During the twentieth century, many Arab movements emerged, influenced by the modern artistic styles that prevailed in Europe after the Impressionist School and the subsequent schools emanating from them such as abstract, expressive and Cubist. Arab governments devoted most of their interests to art and artists, setting the means and possibilities to support artists and encourage them to stand on the status of global, Arab and local art. Through this, Arab artists have emerged with their word and status, sharing creativity with their peers in Europe and the world, including the first professional artist in the United Arab Emirates artist Abdul Qader Mohammed Al Rais. Because the Arab environment is the same, but its elements vary from place to place, so this artist had his methods of expressing that environment.

This study aimed to show the beauty of the Arab Emirates environment and its reflection in the style of contemporary artist Abdul Qader Mohammed Al Rais, an analytical study. Its limitations (2015) consisted of an introduction and three chapters. The first chapter (the theoretical framework) contains four topics, the first topic deals with: Dialectic of the environment and its relationship with the artist. The second topic on: the concept of style in the artwork. And the third topic on: Aesthetic environment of the United Arab Emirates. The fourth topic is: Study of the style of contemporary Emirati painter Abdul Qader Mohammed Al Rais. The second chapter (research procedures) contained the research community and analyzed the sample of the research sample. The third chapter contains the results of the research and then the sources and supplements.

Keywords: Aesthetic, Environment, Style, Contemporary, Abdul Qader Al Rais.

\section{INTRODUCTION:}

For the environment in which man lived since ancient times a direct impact on him, where he wanted to stand on the secrets of nature, which derives the elements of his entire life in eating,

drinking and clothing. Man has reinforced this relationship and its effects by his own exhibitions embodied on the walls of the caves and ceilings and stones, rocks, bones and clay figure, has become to this day a great puzzle and treasures tell the history of the stories were interpreted some of them and others
\end{abstract}


kept secret. His view of nature from a fascinating landscape brought only immediate economic benefits. His paintings were astonished and the language of the world was a message that united artists of different national or religious backgrounds to this day. These scenes simulated nature, including drawings of animals with a variety of subjects, such as being pursued by the artist himself and others in water or in forests. Among the signs of this is the drawings of the artist of the Mesopotamian Valley and the artist of the Nile Valley, which decorated the walls of temples, palaces, ziggurats, pyramids and on the figure of clay, pottery and miscellaneous stones. Remnants of several settlements dating back to the third millennium $\mathrm{BC}$ have also been found in the $\mathrm{Al}$ Ain region of the coastal region of the United Arab Emirates (Klikowski, 1979, p. 13). Then these arts moved to neighboring civilizations such as Greek, Sassanid and other regions of the East to end with distinct Islamic civilization as it relied on various decorative methods and flattening forms when simulating nature, and the realization of reality so earn it an identity of its own, and is evidenced by the drawings of Yahya bin Mahmoud al-Wasiti Iraqi.

However, Europe has many artistic evidence according to the diversity of different environments of artists as distinguished from others with their distinctive creations. The individual is the starting point for everything, for example, in the Mona Lisa painting by the famous Italian artist Leonardo da Vinci (Pretigon, 2005, p. 150), who portrayed Portrait behind him as a naturalist, wanted to move the personal scene dominated by the stalemate despite the vague smile on the lips. After him, many artists, including Constable and Della Croix, emerged who paved the way from the classics and entered the landscapes of living nature (Ibid., P. 63). This was a vertical coup represented in the abandonment of halls and deaf ceremonies and the direction towards the nature-speaking to implement their scenes directly and at many times to embody one or more scenes in different ways (Bowns, 1990, p. 135) Of these (Renoir, Manet, Paul Kukan, Monet, Paul Cezanne and Van Gogh) Van Gogh used a distinct and strange style over the days of his work in art and his relationship with nature was characterized by his technique of painting with amazing brush strokes that explained the fine details of the scene and gave the colors a real dimension that brings him closer to simulating reality according to his vision.

The Arab artist looked at these schools and encyclopedias and found a wide entrance for him to express what is going on in himself and simulate his social reality and environment in which he grew up and took them different titles of his works that became famous and moved local, Arab and international flags in the later years of the history of contemporary Arab art.After adhering to the Impressionist style he inspired from Europe, the Arab artist adopted many methods stemming from changing the external form of nature, such as the schools that were born after Impressionism such as Cubism, abstractism and expressionism. His artistic style then became a series of experiments and attempts to apply his simplistic approach to a number of modern methods. His environment influenced him with various elements in the selection of his subjects. The Arab environment has one particular sense that the Arab person feels to be (language, history, religion often and values, traditions, customs and good qualities are all the same in any Arab country), but the Arab natural environment is different from place to place such as mountains, hills, plains, valleys, rivers, marshes and seas. There is also a divergence in the political, economic and military aspects of the modern era of all Arab countries. Hence, the technical tenders between the Arab countries varied according to the changes in the natural environment and the political, economic and military aspects imposed on them. Through this, the research problem formulated in the form of questions crystallized as follows:

1. What method?

2. What is the concept of the environment?

3. Is the beauty of the environment directly reflected on the Emirati artist Abdul Qader Mohammed Al Rais?

4. What are the contents and trends transmitted by the environment?

5. What are the most important vocabulary or elements that are always repeated in his works? 
6. What techniques and methods are used to represent his environmental art?

7. Were human elements present in these works?

\section{RESEARCH OBJECTIVE:}

This research aims to reveal the beauty of the UAE environment and its reflection in the style of contemporary Emirati artist Abdul Qader Mohammed Al Rais as a basic and aesthetic element in its composition. And identify the techniques by which these fees were implemented.

\section{The importance of research and the need for it}

This study is an attempt to the educational and aesthetic dimensions of environmental expressive art as an art that embodies the objective facts of nature as well as the subjective feelings of the artist contents and ideas and its work is based on the concepts of life of good and right and its implications and communicative and educational dimensions.

a. The study provides analytical readings of the works of realistic and expressive art and the psychological and educational dimensions inherent in them.

b. Benefit researchers in the fields of criticism and modern arts in general and expressive art in particular.

c. Shows the natural and economic beauty of the UAE. And how to express it artistically through the many artistic achievements of the artist Abdul Qader AlRais.

\section{Search limits:}

1) Spatial Limits: United Arab Emirates. The work of the Emirati artist Abdul Qader Mohammed Al Rais, which appeared in art galleries and cultural publications as well as artistic sources

2) time limits: (2015)

3) Objective Limits: The aesthetic of the Arab Emirates environment and its reflection in the style of contemporary artist Abdul Qader Mohammed Al Rais, an analytical study.

\section{DEFINE TERMS:}

Linguistic Environment: The House of the People in the Whole Place (Ibn Manzur, 1999, p. 531).

Idiomatic Environment:

The environment is a collection of things and phenomena that surround and affect an individual. It is said natural environment, internal environment, intellectual environment and social environment. Thus, space and time are called frameworks that surround natural phenomena. It is synonymous with the center of Kaflan among his people (Saliba, 1982, pp. 220-221).

Environment procedurally:

things arising from constructed or natural phenomena that surround the individual and affect the existence, or is a set of systems intertwined with each other to the degree of complexity and affect the individual and determine its survival on this earth.

Linguistic Age:

The age, Allah Almighty said (( By time, Indeed, mankind is in loss )), ( Koran, Surat Al-Asr, verse: 1,2) the age eternal swear by God, which is an hour of the day (Ibn Manzur, p. 252). And his time was of his time (ibid., P. 253).

\section{Idiomatic Age:}

The era in literature is a time period in the history of the development of literature characterized by special features and predominance of the doctrines of literature over other doctrines, and refers to the spirit of the times in literature, as is the case in the proportion of ages to the European schools prevailing in them, such as the classical or romantic era ... (Wahba, 1979, p. 137). Contemporary: a characteristic of a human being or an event whose existence is 
consistent with others at the same time, and if launched to go to the present, such as the contemporary novel, for example (ibid., P. 203).

Table (1) List of sample of the research sample (the work of the artist Abdul QaderAl Rais)

\begin{tabular}{|c|c|c|c|c|c|c|}
\hline series & Subject & Measure & Date & material & $\begin{array}{l}\text { Place of } \\
\text { presentation }\end{array}$ & Source \\
\hline 1) & The boat. & $\begin{array}{l}200 \times 280 \text { inches. } \\
508 \times 711.2 \mathrm{~cm} .\end{array}$ & 2015 & $\begin{array}{l}\text { Oil on } \\
\text { canvas }\end{array}$ & $\frac{\text { Hunar Gallery }}{\text { Dubai }}$ & $\begin{array}{l}\text { https://www.artsy.net/artwor } \\
\text { k/abdul-qader-al-rais-boat }\end{array}$ \\
\hline 2) & The Palm & $\begin{array}{l}787.10 \times 787.10 \text { Inches. } \\
200 \times 200 \mathrm{~cm} .\end{array}$ & 2015 & $\begin{array}{l}\text { Oil on } \\
\text { canvas }\end{array}$ & $\frac{\text { Hunar Gallery }}{\text { Dubai }}$ & $\begin{array}{l}\text { https://www.artsy.net/artwor } \\
\text { k/abdul-qader-al-rais-the- } \\
\text { palm }\end{array}$ \\
\hline 3) & $\begin{array}{l}\text { Of Ghaith } \\
\text { series }\end{array}$ & $100 \times 80 \mathrm{~cm}$. & 2015 & $\begin{array}{l}\text { Oil on } \\
\text { canvas }\end{array}$ & $\frac{\text { Hunar Gallery }}{\text { Dubai }}$ & $\begin{array}{l}\text { https://www.artsy.net/artwor } \\
\text { k/abdul-qader-al-rais-from- } \\
\text { the-al-ghaith-series }\end{array}$ \\
\hline
\end{tabular}

\section{CHAPTER ONE (THEORETICAL FRAMEWORK)}

\section{The first topic}

Dialectic of the environment and its relationship to the artist

The environment is the place where man lives, dies and performs all his different activities, affecting his public and private behavior. The public towards others, such as cooperation with them in various issues in the rural community in particular noticed familiarity and full cooperation between them in order to accomplish work such as the establishment of a house for a particular individual, or in the case of natural disasters such as floods and fires. The private relates to the many activities of the individual in which he tries to overcome the environmental effects so as not to cause him a dilemma or try to employ its elements to serve him. The environment has several types and characteristics such as the plain, mountain, desert, marshland (wetlands), social environment and changing weather environment (Saliba, ibid., Pp. 220-221). These environments should be studied extensively when it comes to their impact on the style of an artist as in this study. When knowing the characteristics of the environment, the researcher finds the real influence in the artist's style. The emphasis is on the importance of studying the interaction between the variables of the organism and its surroundings and finding the relationships between them (Shamaa, 1981, p. 141).The natural environment of man and his social environment and its built environments such as architecture, including the left by the Muslim artist of various architectural monuments such as mosques, castles and buildings with various elements of a beautiful innovative character such as domes (FayrouzAbadi, 2005/ 1426, p. 177. Hadithi, 1974, p. 8. Alfi, p. 132). The different arches and minarets are decorated with various motifs such as vegetation, geometry and composite. The natural environment has provided several aesthetic aspects to the artist that gives him joy and pleasure to help him to give continuity and creativity in it (Mohammed Said, 1410 AH / 1990 $\mathrm{AD}$, p. 259).In nature, life, death, shadow, light, sounds, rain, snowfall, tranquility, roaring waterfalls and desert sandstorms all give people a kind of excitement that enters into the corridors of thinking in their simulations or expressed in any forms and types of thinking, whether in poetry or in art. In the end, it 
is necessary for the artist to turn his experiences into a color of his expression, so that his artistic performance recognizes them to deepen his sense of the big world and the things that surround him (Kalima Magazine, 1972, p. 4).

Human life in the countryside and the desert is characterized by cruelty and drought, so the ancient primitive man was able to live it and overcome it without doubt. They move from one place to another according to the sources of living such as water and pasture, and although their difficult life and interest in living, they were characterized by art and love for art, for example in fashion and dyes, especially henna and tattoos, as well as knitting of various types. And because the Arab artist (Emirati Abdul Qader Mohammed Al-Rais), the title of this study lived in this ancient environment sprawling and noticed the effects of spinning and revival of artistic works very creative, which seems obvious environmental effects, being representative of the inherent heritage of him, can not go beyond his society including It has inherited physical and moral effects, but tried to interact with it because it is part of the fish affected by the rise and fall of water temperature. Every human being has a special motivation to belong to a group of people who needs their love, appreciation, respect and assistance to him. All of this can only be done through interaction with them and accepts their judgments, norms, and social norms and behavioral norms they have agreed to call (social norms or standards of behavior) (Samarrai, 1408 AH / 1988, p. 92).

Artists should rethink their surroundings or created them to reflect their wonderful artistic achievements, they commemorate the change, setbacks, development and monitoring of events to sow the most beautiful ideas and best drawings to create the right atmosphere for creativity and innovation to address those variables or search for the right and rational ways to codify or fade negatives and spread and expand the positives. Hence, the artist has contributed to addressing the combined issues that have not directly affected the enrichment and find appropriate solutions for the advancement, development and prosperity. And spread these artists throughout their environment masterpieces of the ideas produced by their ideas of real values important prevailed in society to expel the false impurities extraneous to him. Therefore, environmental influences give artists the thought of innovation and creativity to produce works that are very creative with the influence of environments. Certainly, art can never be accomplished without any thought. Oh God, except that the form is held without content, or pictures without subjects (Ibrahim, p. 226).

\section{The second topic:}

\section{The concept of style in artwork}

First of all it is necessary to clarify the concept of style before proceeding to study the style of the Emirati artist Abdul Qader Mohammed Al Rais. Style is the way of writing and expressing ideas (Massoud, 1992, p. 74. Talqani, $1414 / 1994$, p. 328.) It is one of the expressive means of the group or of the individual.It is a way that individuals adopt and take, know it and is often called upon philosophers, especially on how to express ideas through this and adopt the types of diverse movements embodied by those ideas (Saliba, ibid., P. 80). The method, then, the human person himself, is the formula, or authorship that embodies the individual qualities and attributes, and the doctrine of each of the writers or researchers in the authorship between the words and images. It is not only different for researchers and writers, but often for different ages as well. To express the meanings he envisioned himself (Saliba, ibid.). The style minerals that arise in the language of expressive means that highlight the aesthetic, emotional, voluntary, psychological and social paradoxes. It is revealed first and foremost in the common automatic language before its emergence in artistic effects (Al-Masadi, p. 41; Giro, 1994, p. 28. Ben Dhiril, 2000, p. 43).

Dry methods with dark, dull, heatless colors have no effects on the breath and do not move them, as in simple natural methods with emotional emotions. In addition to these special methods, imams also have an all-encompassing and universal approach that reflects how the mind influences nature. The methods vary widely among groups and individuals (Saliba, p. 81). It is undoubtedly changing according to the circumstances and meditations because it only comes 
from man himself or follows it in his own way however he wants. Each person has his or her own style that may or may not match his or her colleagues with certain things, Being a characteristic of style, art is undoubtedly the world of art, a method of knowledge or an approach of knowledge that is as valuable to an individual as science or philosophy. (Reid, 1975, p. 17). It is the artist who takes this method to reach the cognitive facts that are obtained only through technical investigation and research,

So he follows a particular method, often called his name. The poet is also an artist, and poetry is an art in which language is especially at the forefront. The poet, the reader, or the listener cannot forget the language in which they are written. (Addman, p. 61). Thus, the poet is the jeweler of words, these formulations have certain methods taken by this poet or that is called by the joy or sadness or others.

The style of the poet, then, corresponds to the style of the artist in terms of the way each expression of what he feels, according to his specialization of each one any difference in the means of expression.

The artistic activity itself is undoubtedly an image of intelligence (Ibrahim, p. 226).

The artist's method and methodology stems from his fertile ideas as well as when the poet after the use of fine in his heritage to paraphrase their own methods of modern and modern methods.

The style is determined not only in poetry or art, but also in ethics and sociology in the approach taken by the individual or groups in their different works, It is said, as the way of life or perhaps called the way the philosopher himself in the expression of his doctrine, such as the philosopher Descartes said: When he did not yet get enough knowledge of man to talk to him in the manner in which the integration of others ... Suffice to impose (Saliba, ibid.). It also means the launch of the method of the author or researcher coordinate his ideas, In this sense the method is harmony and arrangement. It is therefore a varied and multiple art between the individual and the communities. It was unleashed in the modern era and became in harmony with the spirit of the era, which prevailed in prosperity and development and the birth of the means of high-speed expressions such as computers and their relations with the means of global communication (The Internet).

The third topic

Aesthetic environment of the United Arab Emirates

The United Arab Emirates was established on December 2, 1971. It covers an area of 83.6 thousand square kilometers. It consists of seven emirates: $\mathrm{Abu}$ Dhabi comprises $85.8 \%$ of its total area, while Dubai $5.5 \%$, Sharjah 3.3\%, Ras Al Khaimah 2.1\%, Fujairah 2\%, Umm Al Qayoon $1 \%$ and Ajman 0.3\%. The United Arab Emirates is located east of the Arabian Peninsula, southwest of Asia on the southern shore of the Arabian Gulf. It is bordered to the northwest by a common maritime border with the State of Qatar and to the south-east with the Sultanate of Oman and has a common land and maritime border with Saudi Arabia on the west.

Making its privileged position to witness great events through the ages in its rich history full of changes and developments, Its maritime expertise and its diverse fleets play a leading role in revitalizing its trade and diversity due to its view of the three continents of Asia, Africa and Europe across the Indian Ocean, which is the important route and the recognized trade port. (Klicowski, 1985, p. 7). It is also characterized by the diversity of natural environments, including mountains, valleys, plains, deserts and oases. It also has a direct location on the Arabian Gulf coast. This has led to diversity in the distribution and presence of wild and marine flora and fauna, pearl fishing, oil and natural gas discoveries and various natural minerals such as copper, gold, lead, sulfur, iron and uranium. This has increased the diversity of the economy and trade sources in the UAE (ibid., Pp. 8-12).

As a result of the distinguished location of the United Arab Emirates and the abundance of its goods inhabited by human thousands of years ago as evidenced by the research and discoveries of modern archeology (Baqer, 1998, p. 335). Through this, tools and remnants of several settlements dating back to the third millennium $\mathrm{BC}$ have been discovered in the Al Ain region of the coastal region. The remains of Queen Balqis Palace have been found in the Ras Al Khaimah area. The presence of these ruins allows us 
to say that it is not unlikely that the queen of the Arabian Peninsula lived here. Remains of the harbor found off the coast of the Gulf of Oman gave archaeologists a basis to believe that this harbor was a base for the departure of Alexander the Macedonian fleet of India. (Klicovsky, p. 13).

In 1958, during the construction of the bridge connecting land on the island of Umm Al Nar, the remains of an ancient castle dating back to $2300 \mathrm{BC}$ were found. The walls of this castle were built of stones, paved with fine and tight paving. This made archaeologists to expect these drawings to be one of the first signs of the domestication of this animal and domestication by humans of this country, Scientists were also found in this place ... Babylonian, Egyptian, Indian, Chinese and Persian artifacts, indicating the existence of significant trade relations linking this country with other regions. Arab pastoral (Bedouin) and agricultural tribes were also inhabited Agricultural tribes were plowing near oases and valleys where water resources existed, while pastoral tribes traveled throughout the Arabian Peninsula in search of water and pasture. Other coastal tribes practiced fishing (ibid., P. 14).

The ancient Arab tribes that inhabited the territory of the present United Arab Emirates were able to extract iron metals and melt various minerals, they made gold and silver and excelled in them. They also excelled in the construction of tunnels, irrigation systems and dams that were very developed for them (if the development of the United Arab Emirates today has its roots and the extension of its historical horizon, it is no wonder that the grandchildren of the great achievements of the country, such as the two elderly Sheikh Zayed and Rashid God have mercy on them), They drilled wells and canals with highly innovative technologies, some of which are still in use in the UAE today (Ibid., Pp. 14--15).

The United Arab Emirates has occupied a prominent place during the modern era in the Arab and world worlds, especially after the middle of the sixth decade of the last twentieth century, the United Arab Emirates rose and its strength was defined when its late Sheikh Zayed bin Sultan Al Nahyan (19182004) headed its leadership (Al-Hassani, 2011, p. 36). When he became ruler of the Emirate of Abu
Dhabi on August 6, 1966, he administered the country, enhanced the status of slaves, developed a way of life, united the UAE, and enhanced his many achievements by discovering oil in commercial quantities. Oil has increased financial resources and encouraged the establishment of the necessary infrastructure for the whole of the UAE, including the arts.

Political stability, the integration of infrastructure and the economy of the country are directly related to the development and advancement of the arts (Robertson, 2005, p. 16). This is noticeable when the UAE has enjoyed political stability since December 2, 1971, when the Union of the Seven Emirates proved to be a remarkable success. This is a unique one that has established its foundations and strengthened its position as Sheikh Zayed (may Allah have mercy on him) and made it open to the whole world while adhering to local traditions and their authentic Arab-Islamic heritage. Encouraging foreign investment, living standards have improved significantly in the UAE, Huge funds have been poured into building the country's infrastructure, developing its social institutions, creating jobs and diversifying the economy (making it less dependent on oil). Thus improving living standards Accordingly there are plans to develop advanced transportation to include metro, rail and tram systems. Most have been accomplished and are in constant prosperity. The UAE has a preliminary plan to develop atomic energy to meet the huge energy requirements. The United Arab Emirates has become indisputable, especially the Emirate of Abu Dhabi, among the richest people on earth. This was reflected in the arts and the UAE is now well known in this field.

The UAE supported the arts and encouraged its movements and trends. Therefore, there were major artists who changed the course of the artistic history of the UAE from these artists: NajatMakki, Abdullah Al Saadi, Abdul Rahim Salem, Mohammed Ahmed Ibrahim, Ahmed Al Ansari, Hassan Sharif and Abdul QaderAl Rais (the subject of this study). 


\section{Fourth topic}

A study of contemporary Emirati painter Abdul Qader Mohammed Al Rais:

Abdul Qader Mohammed Al Rais was born in Dubai, United Arab Emirates in 1951 (Appendix A). He is the first professional artist in the UAE. Attached to the drawing since his early childhood, deepened him and made his reputation. Children learn to develop forms of objective focus so that they are precious. They are essentially self-centered (Porteus, 2010, p. 50). As he reached his most intense and powerful fingers and multiple methods and with his reputation became the most famous and influential Emirati artists. He still works to this day thanks to his many diverse works spanning from the late 1960s where he excelled in oil, acrylic and watercolors. His topics dealt with documenting his traditional heritage of the UAE and the political and social history of the entire Arab region. Interpretation of nature and theories of Arabic letters, which are the depth and richness of creativity offered by the UAE cultural scene. The artist is known for his abstract works that include geometric shapes and Arabic script. The use of floating squares across the canvas has become a hallmark of his artwork. When art is created, the distribution system forms its cycle, and it is interesting that it sees the international art market as the only mechanism that gives high value to art.(Robertson, ibid., P. 13).

In the past, artists usually exchanged their creations in exchange for something.

Some great works (which are now of great value) will be negligible unless someone pays for them. This money, favoritism and trade undoubtedly spoil the springs of pure imagination, to be commendable imagination (Hughes, 2001, p. 388). This means that there must be a system at work to distribute art and give it value. At the beginning of the 20th century, the UAE was not on the artistic map.

But in just a few years, it has been able to establish itself as a large market and a vast arena for emerging arts, a market capable of attracting steady technical investors. These investors no longer consider the art created in the Middle East to be undesirable, but they are beginning to give it a distinctive character. The art in question may not have changed in the past decades, but there are factors that have allowed this change in perception of value. The artist goes through several circles that lead him to fame, including his many acquaintances with the styles of other artists of his generation and his familiarity with criticism and recognition, and the public's praise (Bowness, 1989, pp. 47-49).

Al-Rais's artistic life spanned about 50 years of continuous tenders. From his early completed pictorial works. Even its modern achievements, which can be undoubtedly recognized through the art of Arabic calligraphy, which is part of the language, are like the homeland in dire need of sincere people. (Hamada, 2000, p. 9). Al-Rayyes found her stray and devoted her sincerity and continued over the past few years to focus on the local scenery that has become a distinguishing mark.

Then at the crucial stage of his career, when he was going beyond traditional watercolor themes strongly associated with his name. Al-Rais advanced beyond himself and began to tackle issues of artistic composition and individual style brilliantly and at a critical distance. Geometric elements and lines were initially added to form multiple illusions of depth to the subject. With this series, he succeeded in making the geometric shapes surrounding the subject matter as important as the subject itself. If seen further the changes in the handling of coloring and intermittent stylistic make the intense differences between his realistic paintings resulting in abstract calligraphy with geometric images and realistic images on new vibrant cloth pieces. The integration of the method is its language in the expression of the purely individual self - this method is not closely related to one hand with powers but is separate, mobile, detachable, and can be resettled by the signature style of Abdul Qader Mohammed Al Rais (https://en.wikipedia.org/wiki/Abdul_Qader_Al_Rais ) .

In his drawings, AlRais explores the complex relationship between man and nature. He depicts heaven, earth and sea through a colorful painting and explores the creation and abilities of God. He looks at purity and looks for the balance of natural elements and examines the conceptual nature of Arabic calligraphy in a continuous series called letters. His 
other works dealt with political and social issues throughout the Arab region such as the Palestinian cause, the Gulf War, and the Syrian crisis. He also documented the UAE's urban landscape as an attempt to preserve its cultural identity and collective memory. He also excelled in drawing portraits, an important part of his work. While in school in Kuwait, he often painted himself and the children around him still living in that environment. In addition to a collection of drawings and studies of the human personality, newspapers and old magazines from the personal archive of artists, revealing many styles and artistic trends in which he excelled $\mathrm{Al}$ Rais. Despite the emergence of modernization and globalization that have changed the contours of the urban environments surrounding it. Traditional Emirati architectural paintings have become towers, and sailboats have served as windows in the past calling for the preservation of the cultural heritage of the UAE. His nostalgic paintings follow the country's roots and humble beginnings. The artist painted mountains, deserts, oases, plants, sea and sky. Here Al Rais seeks an understanding of God's creation, and eventually discovers inner peace. His works reveal his precise observations and assessment of political events and social tensions in the region using surreal and abstract expression techniques. This allows him to express a sense of persistence and deep attachment to the peoples of the Arab world. His impressions are exemplified by the combination of distinctive figurative and abstract forms inspired by landscapes and architecture that share a range of colors. Its characteristic square floats when it refers to traditional houses built of coral brick and clay. As well as the reference to the point (letters), in Arabic letters in the painting he focuses on the letters when moving to the subjective artwork influenced by artists of modern Europe, which is the peak of artistic history (Hourani, 1994, p. 117), And exploring the interpretations of Arabic calligraphy and examines the plastic and conceptual potential of his artistic messages from the Arabic language in particular the letter (Haa and Waw). )(http://web-release.com/landmark-exhibitionemirati-artist-abdul-qader-al-rais-opens-abu-

dhabi/

\section{CHAPTER TWO (PROCEDURES)}

\section{A.Research Society:}

This research includes the artworks of the Emirati artist Abdul Qader Mohammed Al-Rais represented in the limits of the research that the researcher was able to obtain from the following sources:

1- Technical books, guides and available sources.

2. Public institutions.

\section{B. Sample of research sample and justification for selection:}

Sample models were selected intentionally on a regular basis (Table 1, p. 5) based on their terms of reference for analysis:

1) represented in the indigenous community.

2) Be for different environments.

3) The validity of their colors in the analysis.

\section{Approach to analysis:}

The researcher will adopt the analytical approach, which includes analytical structure and a system developed for the work of the sample of the research to the specificity of the research that moves within the framework of an analytical.

\section{Search Tool:}

The researcher identified a tool (observation), for his research, a descriptive analysis of the sample chosen in relation to the characteristics of these works useful research.

\section{The research sample :}

The researcher identified the research sample by identifying his community (works of the artist), the subject of the research identified by three works of this artist. 
Sample Analysis:

Model (1)

Subject: The boat.

Size: $200 \times 280$ inches $508 \times 711.2 \mathrm{~cm}$.

Year of production: 2015.

Material: Oil on canvas.

Source: https://www.artsy.net/artwork/abdul-qader-al-rais-boat.

\section{Subject :}

The natural, social, religious and political environment has had a profound impact on the life of the artist Abdul Qader Mohammed Al Rais, especially when choosing titles for his works that helped him to

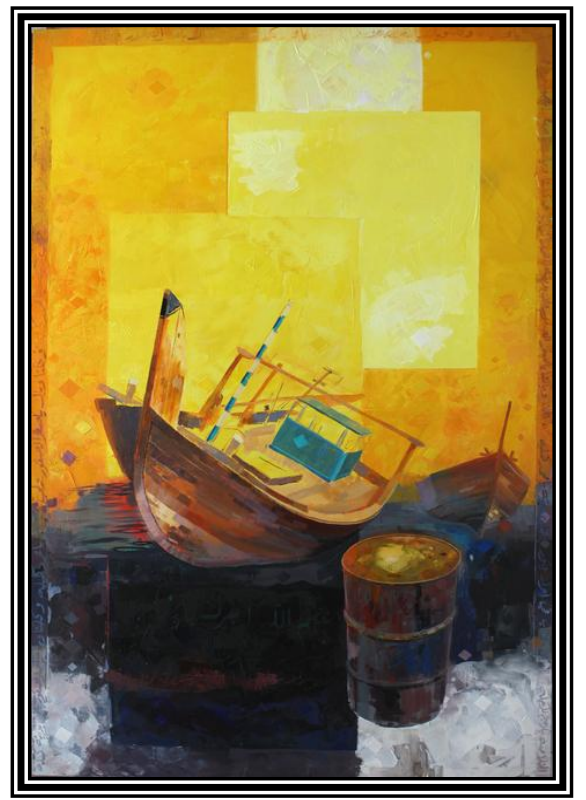
approach the folklore topics. This work is one of the signs that Al-Rais has been interested in in the ongoing search for his heritage. He possesses high craftsmanship and a vast cultural inventory enriching his creative artistic approach to exploring the vocabulary of his past and fragrant shadows. The artist received great acclaim from critics and audiences inside and outside the UAE. Topics include: ancient doors, ships and the sea. His approach with his paintings was able to tell the story of his local heritage, the vocabulary of his environment and his life visually on the pages of his white paintings. In the past, the artist collected pieces of scattered ships as he passed daily by the industrial workshops of ships at Dubai's Al Maktoum Bridge at the time. To put it in his studio to be in front of him to draw. After sensing it touching its surface, his toll from the remains of many ships in his old house. Thus, he contemplates its subject in a local sense. When looking at the boat, the boat's place in the lives of people raised in the shadows of its environments will come to mind. In this sense, he named this artistic achievement to give it a bit of privacy.

\section{General Description:}

This artistic achievement contained a boat with a huge front pillar ending with a black triangle head. In the center of the boat has a small cubic blue-colored room with glass windows in the center to the left of a quadruple-shaped head upward. The boat also has parallel, opposite and intersecting pillars and columns. Colored in blue and white alternately, the center of the slope is slightly oblique to the left of the viewer, based on the bottom in the form of a quadrant. Dominated by the black color contains the writings of the artist himself: (God maximizes your reward, $\mathrm{O}$ homeland). (The war in Yemen, September 3, 2015). And (and Sheikh Mohammed bin Rashid supports his brothers and stands with his brother Sheikh Mohammed bin Zayed in the war and clean Yemen from the scum in which). Behind him is another boat to the right of the viewer and between the two boats an open-lid oil barrel based on a white ground. The colors of the barrel range from blue, yellow, white, red and black. The barrel has two lines in the middle. Behind the main boat is a square yellow background. This background contains three successive yellow quadrilateral shapes one after the other. The middle has a white pigment in its opposite corners. While the last form above it is dominated by white. This artist accomplishes framing a book, a poem consisting of seventeen houses, the title of the poem: We are all soldiers of the homeland, The beginning of the poem: (Conclusion, the leader of the cauldron).

\section{(https://www.elwatannews.com/news/details/800513)}

\section{Configuration:}

The artist tried to balance his artistic achievement by distributing his vocabulary more like symmetry. The artist weighed the void at the top, which is part of the subject matter of the work, with the void and parallel and 
intersecting lines resembling geometry. It was predominantly straight with some quadrilateral, rectangular and triangular shapes, such as in the rear yellow squares and several parts of the boat and underneath. Others are bends, arcs and clear circles in the drum. Also parts of the boat and the symbols (letters) as if dissolved. The contrasting and homogeneous colors are predominantly dark and dark at the bottom, and luminance and clarity at the back to the top. The plate is stable and the construction appears open in a direction parallel to the movement of the two boats. The power of expression and the ingenuity of the design and its response in different, symmetrical and convergent spaces and forms carry connotations of Emirati heritage through its rich history stages. In addition to the color areas that covered the surface of the photographic artistic achievement of a fully integrated unit is separated only by the diagnosis. At the background of the work, the artist identified Al-Rais line of horizon in yellow color with blue and red and in between. The top (space) area occupies two thirds of the original area of this artistic achievement. It has a huge quadrilateral, which has three quadrilateral shapes that overlap each other and have small quadrilateral points. The other lower third includes shapes and vocabularies of two boats and one barrel with some straight lines (horizontal and vertical). Colors ranged from white, green, blue, gray, red, yellow, and walnut coffee. These colors are characteristic characteristic of the artist Al Rais as it became a clear character for most of his work, through which the artist shows a suggestion of the third dimension (perspective). The artist tried to balance the artistic achievement by distributing the forms of mass and the vocabulary of the subject with balanced rhythms overlapping between them. The movement of the opposite boats and the interposition of the yellow quadrilaterals from the top of the middle of the work towards the center, in semi-circular motions. Forming many color lines and flexible blunt separating them. It also contains curved lines to indicate the forms and movements of the boats and the shape of the barrel with curved lines, circular and curved. It is noted in this subject that a realistic feature that is very close to the known Impressionist drawings. The impression of the artist Abdul Qader Al-Rais in most of his subjects makes him to be unique in a manner somewhat close to the modern artistic starting points.

\section{Technic:}

Al Rais used different oil paintings and oil paintings to create his subject on the surface of the artistic work consisting of a canvas and a wooden frame starting with direct painting, reflecting his realistic impression.

\section{Model(2)}

Subject: The Palm.

Size: $787.10 \times 787.10$ in.

$200 \mathrm{~cm} \times 200 \mathrm{~cm}$.

Year of production: 2015.

Material: Oil on canvas.

Source:https://www.artsy.net/artwork/abdul-qader-al-raisthe-palm.

Subject:

Take a local heritage and expressive representation of the natural geographical environment of the artist AlRais. He

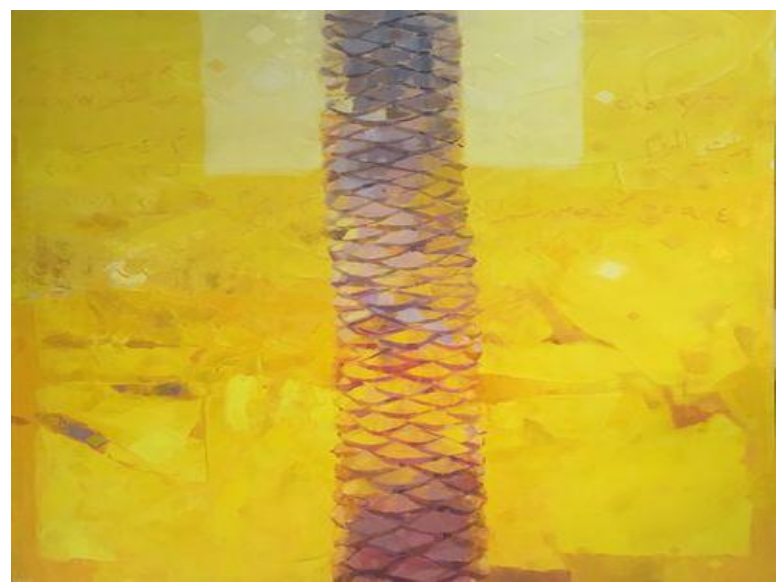
expressed it by employing the natural heritage construction of the Palm Tree. Which held a special and prestigious position when the Arab in particular and botanists in general. In particular, those working in the fields of natural history, which made the Palm has a rich heritage in the human cultural record. The Palm has intervened in human life through the ages to a great extent in the details of his entire life in drink, food, household items, occupations, housing and the vocabulary of his daily life without doubt. The Islamic heritage mentioned the Palm in many places and with great interest and accurate details and was a proverb. In this subject has its own content in the direction of employing the artistic aspects to express the place of the artist in which he lived was the year (the year of 
implementation of this art work). Where the prosperity of life in the ranches of all the United Arab Emirates and increase its beauty when the spring sun shines in heralded immortal immortality, and the dignity of the life of the Emiratis. Expressed by artist AlRais by drawing this palm giving symbol of goodness and generosity and quality and presence in the United Arab Emirates. The Palm also reflects the continuity of life and giving. Embody this by having this palm. Expressed by its huge trunk decorated with the remains of the foundations of the severed palm fronds, they formed regular geometric motifs, such as beehives in the middle of the trunk. Behind the trunk of the palm tree is a yellow, predominantly white rectangle. This is Al-Rais's artistic achievement. And his genius in expression.

\section{General Description:}

This artistic achievement consists of a yellow square area. It contains different vocabulary, most notably a great trunk of a palm that looks tall and important. This can be identified by cutting off their fronds regularly and cleanly. It forms regular geometric shapes like beehives. Behind this trunk is directly centered to the top of the work in the upper third a slightly yellowish white rectangle. The trunk of the palm trunk breaks this artistic achievement into two seemingly identical parts, forming two constituent groups. The first was the right side of the work, in which overlapping numbers and letters written can be identified, some of them say: (20/3/2015 began the decree ... 4/9 of .... month (perhaps meant the month of Ramadan at the earliest),.....). The second group was represented on the left side, containing numbers and letters corresponding to that on the right side, some of which can be read: (Najm ... Abdul Qader ... has been (thankfully) accomplished ... (work) 20/6/2015).

\section{Configuration:}

The artist tried to balance the artistic achievement by distributing the blocks and vocabulary in the style of symmetry, as in the case of Islamic arts. The left block of the artistic symmetry corresponds to the other block on the right side of which is represented by the alphabet and digital vocabulary. This achievement is balanced and stable and construction is open. The human forms did not appear in it. The colors ranged from white, yellow, green, light red, caustic and violet.

These colors seem to characterize the colors of the artist Al Rais in most of his work during the period during which this achievement. The fact that the artist Al Rais areas of these contiguous colors symbolic and expressive blended with abstract realism. Al Rais intentionally showed the third dimension (perspective). The vocabulary of this achievement is more like a geometric ornamental connotation of the trunk of the palm tree. It is determined by the flexible lines and the strength and rigor defined the written and geometric forms contained in the artistic achievement.

\section{Technic:}

The artist Abdul QaderAl Rais used oil paintings in painting on this artistic achievement.

\section{conclusion:}

In this artistic achievement, Al Rais focused on the integrated color abstraction that led him to implement this achievement. He was dominated by the chromatic aberration acquired from his color skills through his various experiences for several decades passed in his practice. Most of these colors combine red, yellow and blue with beautiful combinations and pure creations. Al-Rais incorporated the environment with this abstract and literal artistic achievement by using environmental materials as well as many colors: saffron instead of yellow, which he considers real yellow and a bright color that is not affected by the passage of time. He also used some other spices, but he concentrated only on saffron because he kept his properties and could not. This work revives his love and passion for his environment and heritage. 
Model (3)

Thread: Series of Ghaith.

Size: $100 \times 80 \mathrm{~cm}$.

Material: Oil on canvas.

Date: 2015 AD.

Source: https://www.artsy.net/artwork/abdulgader-al-rais-from-the-al-ghaith-series.

\section{Subject :}

Taking a religious and heritage character to the natural environment of the United Arab Emirates.The artist Abdul QaderAl Rais took care of such artistic achievements. He undoubtedly tried to draw inspiration from the

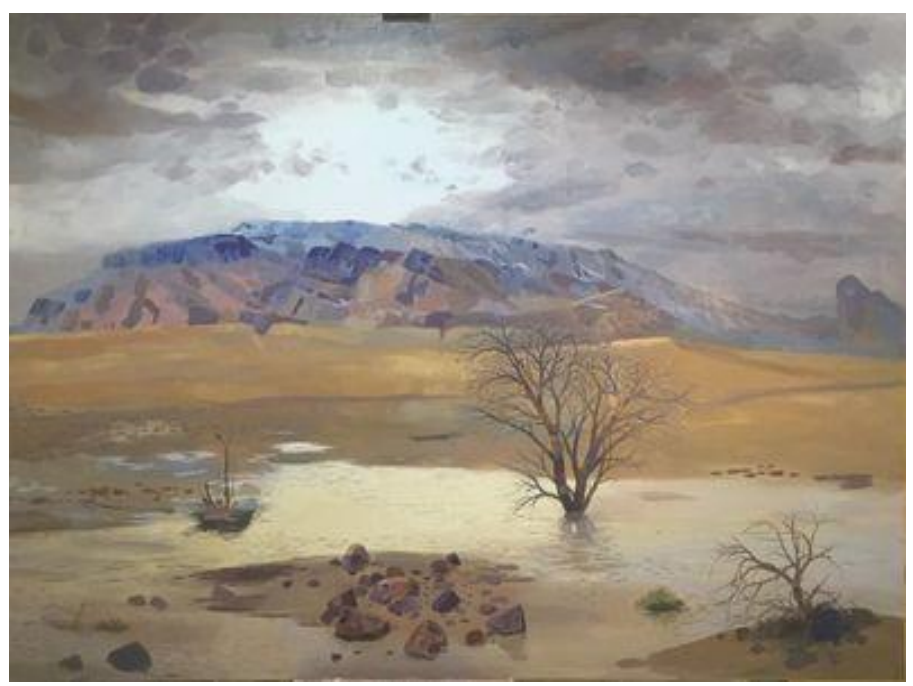
pillars, aspects, values and heritage of his local environment, which he grew up in. The UAE is characterized by a diverse natural environment, but its rich heritage is one and is rooted in its people. The artist Abdul Qader Al-Rais chose an important aspect of his natural environment, and he chose his theme (the series of Ghaith), which he took from the Holy Quran: ((It is He who sends down rain for them after they despaired, and He unfolds His Mercy. He is the Guardian, the Praised.))(Surah Ash-Shura, verse: (28) ) To tell the viewer several messages, the most important of which: (love of God Almighty) for his country and his environment given. This love is represented by the nourishment of the water of the blessed heavens: ((We sent down blessed water from the sky with which We caused gardens and the grains of harvest to grow, )) (Surat Qaf, verse: (9).)

\section{General Description:}

The artist Abdul Qadir Al Rais dedicated heaven and earth to Emirati landscapes and countryside. His artistic achievements are large. The senses are overwhelmed and arouse concerns and reflect the colors and shades of nature in his charming town. The artist is increasingly determined to draw sand deserts, sea, sky, mountains, oases, plants and beautiful nature, all of which contain different vocabulary and landmarks. Al Rais strives to understand the origins of God's creation and to discover the verses of beauty and the creations of that creation. The artistic achievement contained a large mass. It occupies two-thirds of the plate down and is represented by steep mountain heights on some sides and others with simple curves and concavities. Ends with diverse plains and valleys. The plain in front of the scenes is filled with rainwater. Which is home to three thirsty bushes. Greenery melted summer heat and drought and autumn deficit and selfishness and the cruelty of winter and cold, the rain brought to life the dewy spring, which will re-raise greenery again. This lower mass is topped by a space (the upper first third of this work). It represents a collection of cumulative clouds filled with the blessed waters of the sky. It turns out that the land was abundantly sprinkled, and those clouds were drained by the evangelistic winds towards other Emirati lands. To help the UAE land again and quench its thirst in preparation for growth, greenery and livelihood (spring). This is recognized by the great gap that rises above the top of the mountain mass. To show the bright light of the sky light color translucent reflected on the clear waters of Ghaith, which decorates the earth thirst and gives hope and optimism.

\section{Configuration:}

The artist Al Rais tried to balance his artistic achievement by distributing the forms of the large mass with balanced rhythms. Enter from the top center of the board facing down towards the work center.To spread to the left and right of the center, forming blocks with flexible and smooth color lines blunt at times as within the limits of 
water Ghaith and branches of shrubs and parts of the accumulated clouds and sand curves domes in many parts of the subject.

Again, very sharp is indicative of the expressive power of this scene as in the edges of the mountain range and rocks. These lines separate these blocks and also contain small curved lines in the form of semi-circular domes.The granules of the droplets of residue of rain falling on the surface of the water, as seen in the last lower third in front of the viewer.These blocks also appear compact and overlapping.The representation of the foundation and the immortal message that the artist wanted to convey to the local and global audience: the words of God Almighty and is the truth: ((who perfected everything He created. He originated the creation of the human from clay,)). (Surah AlSajdah Verse: (7))He wanted to express it, and this description was derived from the nature of the subjects of artworks artist AlRais.The colors of this artistic achievement ranged from white, light celestial, yellow, yellowishwhite, red, lead and neutral, to coffee.

\section{Technic:}

The artist used brushes and oil paintings in the canvas to produce this artistic achievement, and these colors appear transparent and thus close to transparent water colors to a close.

\section{CHAPTER THREE}

\section{Results:}

1. It emerged that the method is the way of writing and expressions of ideas and means of expression for the group or the individual. A path that individuals adopt, take and know. Philosophers are often called especially on how to express ideas. It embraces the kinds of diverse movements embodied by these ideas.

2. It emerged that the environment is things arising from constructed or natural phenomena that surround the individual and affect its existence. They are complex systems that are intertwined with complexity and affect the individual and determine his or her survival on the ground.

3. It appeared that the natural environment has a profound impact on the life of the artist Abdul Qader AlRais. It appeared in the selection of titles for his respective works. The natural environment helped him get closer to the themes of his folklore.

4. It appeared that most of the artist's subjects took it from his local heritage, such as old doors, ships and the sea. His approach with these paintings was able to tell the story of his local heritage and the vocabulary of his environment and his life visually on his paintings, especially wooden ships. He was inspired by the pillars, aspects and heritage of his local environment in which he grew up.

5. appeared several contents and directives environmental broadcast on the artist flooded his senses and raised concerns and reflected the colors of nature and shadows in his country. It made him increasingly determined to paint the deserts of sand, sea, sky, mountains, oases, plants and nature all with its vocabulary and features. The artist sought to understand the reservoir of God's creation and discover the verses of beauty and the creations of that creation.

6. The social environmental effects in the paintings of the artist, which are essential elements in the composition of these works.This was evidenced by the link between the title of the work of art and its content expressed by the artist's first human experience in the place of (his upbringing), which this artist felt that it has a special composition and appearance.This privacy reflected on his experience in it and thus the research took the impression of the forms and vocabulary and remember to the human situations in which involve a great deal of impressions formed in the origin of this artist. Thus, the art of impression and consciousness were combined by the artist to express the most important feature of his natural environment. 
7. It appeared that the artist has a special style with his personal presence in the art productivity body.The elements and forms to which the artist belongs or is expressed by the emergence of a prominent treatment of the heritage of humanity and the general forms of which were addressed through a variety of topics granted by this feature.

8. The artist used the explicit geometric line and flexible lines in determining the forms of his art work, and sometimes only identify those forms in color blocks. Human elements did not appear in his artistic achievements and resorted to drawing the environmental vocabulary in which he lives and has symbolic significance. He used oil paintings and various brushes to paint the canvas on a wooden frame as a technique to complete all his artwork.

\section{SOURCES}

\section{The Holy Quran.}

1. Al-Alfy, Abu Saleh, Islamic art, its origins and philosophy, and its schools, Dar AlMaarif, Egypt.

2. ALFayrouzAbadi, Dictionary surrounding, Al-Resala Foundation, 2005/1426.

3. Al-Hadithi, Atta and Hana Abdul Khaliq, Conical Domes in Iraq, Baghdad, Directorate of Antiquities, 1974.

4. Al-Hassani, Hamad Ali Hassan, Political Thought of the late Sheikh Zayed bin Sultan Al Nahyan, Founder of the United Arab Emirates (1966 - 2004), Ph.D. Thesis, University of Durham, UK, 2011.

5. Al-Kalima Magazine, First Issue, Fourth Year, January, Dar Al-Sa'a Press, Baghdad, 1972.

6. Al-Masadi, Abdul Salam, stylistic and style, the Arab Book House, $3^{\text {rd }}$ Edition.

7. Al-Samarrai, HashimJassem, Introduction to Psychology, Munir Press, 1408 /1988.

8. Baqer, Taha, Kalkamish epic and other stories about epics and the flood, publications of the Ministry of Culture and
Information, Republic of Iraq, a series of studies (202), Freedom House for printing, Baghdad, 1400-1980.

9. Bin Dhiril, Adnan, Text and stylism between theory and practice, published by the Arab Union, Arab Writers Union Press, Damascus, 2000.

10. Bowness, Alan, Terms of Success: How Modern Artists Rise to Fame, The Times and Hudson, London, 1989.

11. Bowns, Alan: Modern European Art, Translation: Fakhri Khalil, Review, Jabra Ibrahim Jabra, Dar Al-Mamoun for Translation and Publishing, Baghdad, 1990.

12. Edman, European, Arts and Human Brief Introduction to Aesthetics, Egypt Printing House, Cairo.

13. Giro, Pierre, stylistic translation, Dr. MuntherAyashi, Center for Development Revival, Computer House for Printing Aleppo, 2nd edition, 1994.

14. Hamada, Shawki, Dictionary of Wonders of the Language, Dar Sader, Beirut, Lebanon, 2000 .

15. Hourani, Albert, Islam in European Thought, Eligibility for Publishing and Distribution, Beirut, 1994.

16. Hughes, Robert, Nothing if not Critical: Selected Essays on Art and Artists, Banzer, London, 2001.

17. Ibn Manzoor, The Tongue of the Arabs, House of Revival of Arab Heritage, Beirut, $3^{\text {rd }}$ Edition, 1999.

18. Ibrahim, Zakaria, artist and man, Gharib Library, Cairo.

19. Klickowski, R. F. , P. a. Lutskiyevich, Socio-Economic Dilemmas of Developing Countries (United Arab Emirates), Translated into Arabic: Hassan Ishaq, Dar Maysal, 1979, Goli Company, AB Printing Press, $1^{\text {st }}$ Edition, 1985.

20. Masoud, Jubran, Al-Raed (Modern Dictionary of Linguistics, Dar Al-Ilm for the Millions, Beirut - Lebanon, 7th March, 1992. 
21. Mohammed Saeed, Abu Taleb, Artistic Psychology, Higher Education Press in Mosul, Mosul, (1410 AH / 1990 AD).

22. Mola, Ali, The Arab Encyclopedia, Volume I, Syrian Arab Republic, Damascus, $1^{\text {st }}$ Edition, 1998.

23. Porteus, c. Douglas, Environmental Aesthetics (Ideas, Policies, and Plans), Transilation: ArefHadifa, Public Achievements of the Syrian Public Book Association, Ministry of Culture, Damascus, 2010.

24. Pretigon, Elizabeth, Beauty and Art 17502000 (Oxford History of Art), Oxford University Press, New York, USA, $1^{\text {st }}$ Edition, 2005.

25. Reed, Herbert, Art and Society, Dar AlQalam, Beirut, 1975.

26. Robertson, Ian, Understanding and Managing International Art Markets, Routledge, London, 2005.

27. Saliba, Jamil, Philosophical Dictionary, $1^{\text {st }}$ Edition, Lebanese Book House, Beirut, 1971.

28. Saliba, Jamil, the small philosophical dictionary, $1^{\text {st }}$ Edition, the Lebanese Book
House, Beirut, Lebanon, the school library, Beirut, Lebanon, 1982.

29. Shamaa, Naima, personality, (theory, evaluation, research methods), University of Baghdad Press, Baghdad, 1981.

30. Talqani, Abu al-Qasim Ismail IbnAbbad bin Abbas bin Ahmed bin Idris, the periphery in language, investigation: Sheikh Mohammed Hassan Al-Yassin, the world of books, Beirut, Lebanon, $1^{\text {st }}$ Edition, 1414 / 1994.

31. Twentieth Century Knowledge Circle, Mohamed FaridWagdy, M. 6th, $3^{\text {rd }}$ Edition, Dar Al Marefa, Beirut, 1971.

32. Wahba, Magdi and Kamel El-Mohandes, Dictionary of Arabic Terms in Language and Literature, Beirut, 1979.

33. https://www.elwatannews.com/news/details/ 800513

34. https://en.wikipedia.org/wiki/Abdul_Qader Al_Rais

35. https://en.wikipedia.org/wiki/Abdul_Qader_ Al_Rais

36. http://web-release.com/landmark-exhibitionemirati-artist-abdul-qader-al-rais-opens-abu$\underline{\text { dhabi/ }}$

\section{APPENDICES:}

(A) Emirati artist Abdul Qader Mohammed Al Rais. https://en.wikipedia.org/wiki/Abdul_Qader_Al_Rais

Abdul QaderAl Rais was born in 1951 in Dubai, United Arab Emirates. His artistic career began at the age of 14 after his father's death, when his mother sent him to Kuwait to live with his sister. He was very lucky that the Kuwaiti government supported art at the time, so he was able to get all the art materials he needed for free. His talent appeared early and was a gift from God to him, he said. He stayed with his sister in Kuwait until he was 18 years old where he finished his basic education. His early experiences in Kuwait, especially the teachings, influenced his technical and intellectual development.

In 1974 he worked in the Ministry of Labor as a labor inspector and continued his further education by obtaining a degree in Sharia at the UAE University, Al Ain. Then he completely stopped painting for 12 years. He resumed painting again and received the first honor for

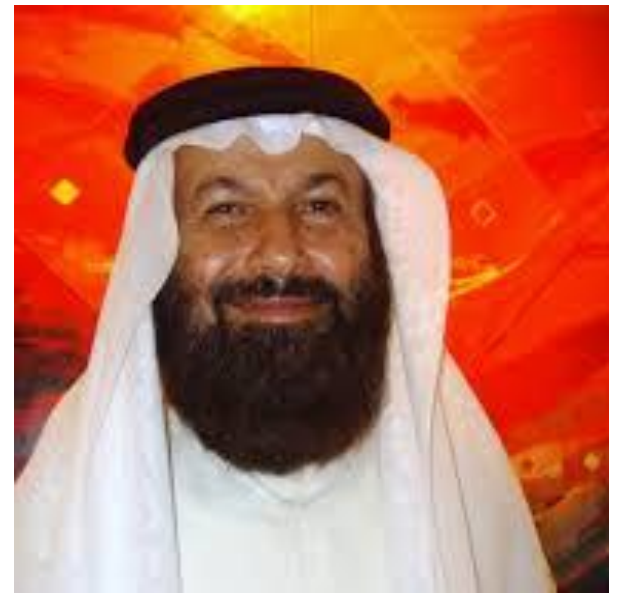


his artwork inspired by the film, Purgatory and Ecstasy. Received several awards, attracted the attention of national and international media. It has become a household name in the world of plastic arts in the GCC. Founding member of the Emirates Fine Arts Society and one of the pioneers of contemporary art in the UAE. Known mainly for his abstract work, and widely exhibited both inside and outside the UAE, his works can be found in Emirati mansions, government offices and personal collections of members of the royal family in Dubai. Over the past few years he has continued to focus on local scenery that has become his brand. His artwork was used to decorate Dubai Metro wagons in 2015 as part of the Dubai Art Season. His art was included in a group exhibition in Berlin entitled Art Nomads - Made in the Emirates, which represents contemporary Emirati art and culture in 2016.

\section{Individual exhibitions}

1974 - Solo Exhibition - Dubai; 1987 - Dubai, Sharjah; 1988 - Dubai; 1989 - Abu Dhabi; 1990 Dubai, 1991 - Abu

Dhabi, Dubai; 1992 - Prague, Liberec, Czechoslovakia, Beirut; 1993 - Washington DC; 1994 - Al Ain, Dubai; 1996 : Abu Dhabi, Germany, Dubai. 1997 - Abu Dhabi, Dubai, Sharjah Biennial; 2001 - Abu Dhabi, Kuwait, Dubai, Al Ain; 2002 - Qatar 2003 Dubai, 2004 Dubai, 2005 - Dubai, Oman; 2007 - Dubai, Abu Dhabi; 2008 Dubai, Riyadh.

\section{Selected Awards}

1975 First Prize, First Youth Exhibition, Dubai.

1983 Certificate of Appreciation, Arab Painter Exhibition, Kuwait.

1988 First Prize, Third Spring Exhibition, Abu Dhabi.

- Second Prize, Fourth Spring Exhibition, Abu Dhabi.•1990 First prize, 6th Emirates Exhibition - Abu Dhabi.• 1991 First Prize, First Emirates Exhibition - Al Ain.•1990, 1992, 1993 Golden Dana Award - Kuwait. • 1993 Jury Award, Sharjah Biennial, UAE. 1992, 1994 and 1996, the first Sultan Al Owais Award for Scientific Studies and Creativity - United Arab Emirates. 1995 Jury Prize Lattakia Biennial - Syria. •1997 Honored at Sharjah Biennial - UAE.• 1999 First prize exhibition "Emirates in the eyes of its people". 1999 Golden Sawaf (Palm Leaf), GCC Exhibition.• Emirates Award 2006. 2016 First prize exhibition "UAE in the eyes of its people" 